\title{
RESISTENSI TOKOH UTAMA TERHADAP AGAMA DALAM NOVEL ATHEIS
}

\author{
Linda Ayu Darmurtika \\ Dosen Program Studi Pendidikan Bahasa dan Sastra Indonesia, Universitas Muhammadiyah \\ Mataram \\ Email : lindaayu_darmurtika@yahoo.com
}

\begin{abstract}
ABSTRAK
Novel Atheis karya Achdiat Karta Mihardja yang diterbitkan Balai Pustaka pada tahun 1949, bertemakan agama dan berlatar sosial budaya masyarakat Bandung/perkotaan, yang terpengaruh oleh modernisasi/kebudayaan Barat. Penelitian ini memfokuskan analisis terhadap tokoh utama yang mengalami pergulatan batin karena menyangsikan kebenaran agama, sehingga melakukan resistensi. Berdasarkan problematika latar belakang di atas, maka permasalahan yang diangkat dalam penelitian ini sebagai berikut: (1) Bagaimanakah bentuk resistensi tokoh utama terhadap agama dalam novel Atheis? (2) Faktor-faktor apakah yang menyebabkan tokoh utama melakukan resistensi terhadap agama dalam novel Atheis? (3) Bagaimanakah dampak dan makna resistensi tokoh utama terhadap agama dalam novel Atheis?. Bentuk resistensi tokoh utama terhadap agama dalam novel Atheis diurai berdasarkan hasil penelitian, yakni adanya bentuk resistensi yang dilakukan melalui penyangsian terhadap agama dan perlawanan terhadap ideologi agama. Faktor-faktor yang memengaruhi terjadinya resistensi, yakni berasal dari faktor keluarga, agama Islam, lingkungan modern, dan faktor ekonomi. Resistensi tokoh utama terhadap agama dalam novel Atheis dan konteksnya di masyarakat berdampak positif, yakni semakin kuatnya keimanan seseorang dan dampak negatifnya, agama akan kehilangan makna esensialnya, sedangkan makna resistensi tokoh utama terhadap agama, yakni terjalinnya kesadaran dalam kehidupan sosial dan kesadaran dalam beragama.
\end{abstract}

Kata kunci: agama, modernisasi, dan hegemoni

\section{Pendahuluan}

Novel adalah karya fiksi, merupakan cermin masyarakat. Salah satu contoh karya sastra dalam kesusastraan Indonesia adalah novel Atheis karya Achdiat Karta Mihardja. Novel Atheis berlatar di Bandung tahun 1947, menceritakan tentang seorang tokoh yang bernama Hasan yang taat beragama. Menginjak usia dewasa, keyakinannya semakin kuat sehinggga ia menjadi seorang kiai. Namun, keyakinan tersebut diuji ketika ia bekerja di Bandung. Pendiriannya tentang agama mulai goyah ketika ia bertemu kawan lamanya, Rusli.

Dalam hitungan bulan, Hasan mulai meninggalkan kewajibannya sebagai seorang muslim dan arah pandangannya telah berubah dari dunia mistik ke realistik. Perubahan sikap tersebut membuat Hasan berani menentang orang tuanya dengan argumen seperti yang dilontarkan Anwar dan beberapa kawannya.

Penyakit tbc yang diderita Hasan semakin parah dan keadaan Bandung sedang terancam oleh pasukan Jepang. Suasana mencekam, karena semua aliran listrik terputus. Terdengar beberapa kali tembakan dan peluru mengenai Hasan. Dia meninggal dalam ucapan Allahu Akbar.

Isi cerita mengenai pergulatan kebenaran agama merupakan tema pokok. Melalui tokoh Hasan keyakinan seorang muslim mulai tergoyahkan ketika lingkungan sebagai sarana utama yang menyebabkan berubahnya pandangan mengenai agama yang merupakan sumber kebenaran. Agama adalah wahyu Tuhan, yang harus diterima. Namun, pernyataan bahwa agama merupakan wahyu mengalami banyak pertentangan dari kaum atheis atau 
agnostik yang tercermin melalui tingkah-laku Anwar atau Rusli dalam tokoh cerita.

Penelitian ini mengungkap resistensi tokoh utama terhadap agama. Resistensi tersebut lahir karena tokoh utama mengalami pergulatan batin ketika ia mulai mempertanyakan tentang agamanya, karena melihat kenyataan hidup di era modernisasi. Agama adalah sumber kebenaran, tetapi tidak jarang seseorang yang berlatar belakang agama melakukan perbuatan yang menyimpang.

Penelitian ini bertujuan untuk menggali dan mengkaji resistensi tokoh utama dalam novel Atheis serta konteksnya di masyarakat Denpasar sebagai salah satu upaya peningkatan kesadaran terhadap masuknya kebudayaan Barat/modernisasi. Penelitian ini juga bertujuan menghasilkan sebuah deskripsi analitis tentang perubahan sikap tokoh utama dan masyarakat dalam menyikapi sebuah agama.

Penelita ini diharapkan dapat memperkaya khazanah dan pengembangan ilmu di bidang Kajian Budaya dengan menggunakan karya sastra sebagai objek primer. Manfaat praktis penelitian ini, agar dapat diungkap makna dan amanat cerita baik secara eksplisit maupun implisit yang dapat dipakai sebagi pedoman dalam realitas kehidupan.

\section{Metode Penelitian}

Metode yang digunakan adalah metode kualitatif dengan pendekatan hermeneutik yang teknik pengumpulan datanya melalui kartu data dan teknik dokumen. Sistem kerja dari teknik ini adalah dengan cara membaca karya sastra sebagai objek penelitian secara berulangulang untuk mendapatkan pemahaman yang mendalam.

Penelitian ini juga memanfatkan teknik wawancara kepada masyarakat sebagai informan untuk melengkapi data yang diperlukan dalam analisis. Unsurunsur atau data yang terkait dengan analisis kemudian diberi tanda, selanjutnya dimasukkan ke dalam kartu data sebagai instrumennya, serta dikelompok-kelompokkan. Teknik studi kepustaka atau dokumen ini dilakukan dengan memanfaatkan isi dokumen atau pustaka-pustaka yang ada seperti literatur, hasil-hasil penelitian, jurnal, dan dokumen penting lainnya, untuk mendapatkan data yang kiranya memungkinkan dipakai sebagai penunjang analisis sehingga akan mendapatkan hasil yang optimal.

Wuisman (1996:300) menyatakan bahwa analisis data kualitatif adalah metode pemadatan data dengan cara mengembangkan taksonomi, sistem klasifikasi deskriptif atau klasifikasi kronologis yang mencakup jumlah yang terkumpul dan menunjukkan keterkaitannya secara sistematis. Untuk menjelaskan dan melengkapi analisis data, maka data yang didapat dari teks novel Atheis dan sumbersumber yang relevan serta data dari informan melalui teknik pengumpulan data, masih merupakan data umum walaupun sudah dikelompok-kelompokkan di dalam kartu data. Selanjutnya seluruh data yang ada dalam kelompok masing-masing, disortir dan dianalisis untuk mendapatkan data penunjang yang dapat menjawab permasalahan dalam penelitian.

\section{Hasil dan Pembahasan}

Agama merupakan wahyu dari Tuhan yang mengandung nilai kebenaran dan bersifat baku seringkali dipertentangkan oleh kaum atheis, karena berpandangan bahwa agama tidak lagi mendatangkan keberkahan. Berdasrkan pandangan tersebut, maka berbagai upaya dilakukan manusia untuk mewujudkan kebahagiaan hidup dengan menciptakan alat yang serbacanggih. Refleksi dari kehidupan tersebut tidak terlepas dari pengaruh modenisasi yang bersumber dari kebudayaan Barat, yang menghegemoni serta membawa dampak negatif dalam terwujudnya masyarakat yang berlandaskan agama. Moderniasai dalam penelitian ini dianggap sebagai bencana yang mengakibatkan agama mengalami pergeseran makna, sehingga manusia meninggalkan hakikatnya sebagai makhluk ciptaan Tuhan. Berdasarkan problematika tersebut, maka permasalahan yang diangkat dalam penelitian ini sebagai berikut: (1) Bagaimanakah bentuk resistensi tokoh utama terhadap agama dalam novel Atheis? (2) Faktor-faktor apakah yang menyebabkan tokoh utama melakukan resistensi terhadap agama dalam novel Atheis? dan (3) Bagaimanakah dampak dan makna resistensi tokoh utama terhadap agama dalam novel Atheis? 
Berdasarkan permasalahan tersebut, makan dari hasil penelitian dapat diungkap bahwa bentuk resistensi yang dilakukan, yakni melalui penyangsian terhadap agama dan perlawanan terhadap ideologi agama. Jalaluddin (2008:159) berpendapat bahwa agama tidak dapat dipisahkan dari kehidupan manusia. Pengingkaran manusia terhadap agama agaknya dikarenakan faktor-faktor tertentu baik yang disebabkan oleh kepribadian maupun lingkungan masing-masing. Namun, untuk menutupi atau meniadakan sama sekali dorongan dan rasa keagamaan tampaknya sulit dilakukan. Manusia ternyata memiliki unsur batin yang cenderung mendorongnya untuk tunduk kepada zat yang gaib. Ketundukan ini merupakan bagian dari faktor intern yang dalam psikologi dinamakan pribadi atau hati nurani. Mengacu pada pendapat yang telah diurai, bahwa persepsi terhadap agama tidak terlepas dari kehidupan psikologis manusia. Seprti yang dialami tokoh utama dalam novel Atheis, yang melakukan resistensi baik dalam bentuk penyangsian terhadap agama maupun perlawanan terhadap ideologi agama dan resistensi tersebut dilakukan atas persepsinya terhadap agama.

Faktor ekonomi yang memadai atau sebaliknya, seringkali menjadikan seseorang menyimpang dari ajaran agama atau semakin beriman kepada Allah Swt. Namun, di tengah arus modernisasi yang tantangannya begitu besar, maka seseorang banyak terjerumus dalam pergaulan yang salah, sehingga,ajaran agamanya ditinggalkan. Hal ini terjadi pada tokoh utama dalam novel Atheis. la melupakan agamnya karena merasa tercukupi secara finansial/ekonomi. Keluarga, agama Islam, lingkungan modern, dan faktor ekonomi merupakan faktor-faktor yang memengaruhi resistensi tokoh utama terhadap agama. Tokoh utama berusaha melawan faktor-faktor tersebut, tetapi ia tetap terjerumus ke dalamnya. Dengan demikian, teori hegemoni merupakan salah satu teori yang digunakan dalam menganalisis resistensi tokoh utama yang dipengaruhi oleh beberapa faktor tersebut.

Berdasarkan rumusan masalah yang ketiga, maka hasil penelitian ini juga mengungkap bahwa agama di tengah masyarakat saat ini/masyarakat modern telah kehilangan maknanya, sehingga manusia meninggalkan hakikatnya sebagai makhluk ciptaan Tuhan. Hal ini tecermin melalui resistensi yang dilakukan oleh tokoh. Digunakan juga teori resepsi secara sinkronis, yakni penelitian resepsi terhadap sebuah teks sastra yang menggunakan tanggapan-tanggapan pembaca yang berada dalam satu periode. Dengan teori resepsi ini maka kehadiran dan penentuan informan menjadi penting. Melalui informanlah sumber data skunder akan lahir yang kemudian diolah serta dianalisis untuk memperoleh hasil penelitan yang memiliki hubungan erat antara teks dalam karya sastra/novel Atheis dengan konteksnya dalam masyarakat saat ini/masyarakat modern.

\section{Simpulan dan Saran \\ A. Simpulan}

Novel Atheis karaya Achdiat Karta Mihardja yang terbit pada tradisi Balai Pustaka merupakan salah satu novel yang banyak memberikan informasi tentang kondisi masyarakat sebelum globalisasi, hingga masyarakat sekarang di era modern. Berdasarkan tema mengenai agama, maka hingga sekarang novel ini masih banyak diapresiasi meskipun tergolong novel lama. Permasalahan mengenai agama akan tetap menjadi permasalahan baru di tengah kehidupan masyarakat, terlebih dalam masyarakat modern.

Sesuai dengan permasalahan pada rumusan masalah dan tujuan penelitian, maka dapat diambil kesimpulan sebagai berikut. Pertama, berdasarkan hasil pembahasan, maka novel Atheis termasuk karya sastra bermutu dan mengandung unsur-unsur kekinian tentang proses pencarian nilai hakiki sebuh agama di tengah arus modernisasi, ketika agama tidak hanya diyakini sebagai wahyu dari Tuhan, sehingga muncul berbagai persepsi. Munculnya berbagai sudut pandang dalam pemaknaan sebuah agama, menyebabkan seseorang/tokoh utama melakukan resistensi berdasarkan pengalaman dan pengetahuannya.

Kedua, bentuk resistensi/perlawanan yang dilakukan oleh tokoh utama melalui penyangsian terhadap agama, bermakna bahwa ketika sesorang mempertanyakan suatu hal, maka akan terjadi pertentangan dalam dirinya, karena 
pemahaman seseorang dengan orang lain tidak selalu sama meskipun terhadap suatu objek yang sama. Bentuk resistensi yang dilakukan tokoh utama juga melalui ideologi agama, yang berarti bahwa Islam bukan hanya agama, melainkan juga ideologi yang mengandung makna impisit untuk menguasai. Faktor-faktor yang menyebabkan tokoh utama melakukan resistensi terhadap agama, yakni dipengaruhi oleh faktor keluarga, agama Islam, lingkungan modern, dan faktor ekonomi. Adanya faktor-faktor tersebut melahirkan pemaknaan terhadap resistensi yang dilakukan oleh tokoh utama, yakni bagaimana lingkungan sosial dan lingkungan agama memaknainya.

Ketiga, dalam pembahasan digunakan teori hegemoni, persepsi, dan resepsi. Melalui teori-teori ini dipaparkan bagaimana kuatnya pengaruh hegemoni modernisasi terhadadap psikologi tokoh utama. Namun, melalui teori persepsi tokoh utama mampu memaknai bahwa pada hakikatnya agama hanya menawarkan kebaikan atau kesejahteraan bagi setiap pemeluknya. Sedangkan dalam teori resepsi, sumber data tidak hanya diperoleh dari novel Atheis, tetapi dari tanggapan pembaca melalui informan yang telah ditentukan, sehingga dapat diketahui dampak dan makna resistensi tokoh utama terhadap agama, yakni agama di tengah arus modernisasi telah kehilangan maknaknya. Agama pun dipandang tidak lagi membawa berkah, tetapi sebaliknya. Adanya data dari informanlah akhirnya terjadi hubungan yang erat antara teks sastra dengan konteksnya di masyarakat dalam penelitian ini.

\section{B. Saran}

Sesuai dengan judul tesis ini Resistensi Tokoh Utama terhadap Agama dalam Novel Atheis tersirat makna bahwa penelitian belumlah bersifat final, karena begitu luasnya cakupan bidang kajian budaya. Dengan demikian, maka peluang untuk mengkaji novel Atheis menggunakan teori postmodernisme masih terbuka bagi peneliti lainnya dalam mengkaji karya sastra menggunakan konsep bentuk, fungsi, dan makna.

Berangkat dari wacana di atas, maka peneliti berharap kepada peneliti selanjutnya baik dari bidang ilmu sosial maupun filsafat agar tidak menganaktirikan karya sastra sebagai objek kajian, karena karya sastra merupakan refleksi kehidupan masyarakat, sehingga dapat pula dikaji dengan menerapkan teori-teori lain di luar teori ilmu sastra. Penelitian ini juga diharapkan memberi kontribusi bagi masyarakat pada umumnya dan masyarakat Kota Denpasar khususnya, mengenai pentingnya kesadaran beragama di tengah arus modernisasi, seperti saat ini. Sesuai dengan perkembangan ilmu pengetahuan, maka hendaknya penelitian selanjutnya lebih sempurna dari penelitan sebelumnya. Penelitian terhadap novel Atheis ini dirasakan masih belum sempurna sesuai dengan tuntutan kontribusi ilmu pengetahuan, karena masih banyak hasil pemikiran para teorikus yang belum terjangkau oleh peneliti. Namun, hasil penelitian ini diharapkan pula menjadi pedoman bagi peneliti selanjutnya untuk mengembangkan teori-teori yang ada dan relevan dalam paradigma kajian budaya.

\section{Daftar Pustaka}

Ahyadi, Abdul Aziz. 1995. Psikologi Agama. Bandung: Sinar Baru Algesindo.

Arif, Syaiful. 2010. Refilosofi Kebudayaan. Jogjakarta: Ar-Ruzz Media.

Barker, Chris.2009. Cultural Studies, Teori \& Praktik (terj. Nurhadi). Yogyakarta: Kreasi Wacana.

Budiarsa, I Wayan. 2012. "Komodifikasi Dramatri Gambuh di Desa Batuan, Sukawati Gianyar".

(Tesis Program Studi Kajian Budaya, Universitas Udayana, Denpasar).

Daryanto. 1998. Kamus Lengkap Bahasa Indonesia. Surabaya: Apollo.

Echols John M. dan Hassan Sahdily. 2010. Kamus Inggris Indonesia: An English Indonesia Dictionary. Jakarta: Gramedia.

Endraswara, Suwardi. 2008. Metodologi Penelitian Sastra: Epistimologi, 
Model, Teori, dan Aplikasi. Yogyakarta: MedPress.

Hidayat, Komaruddin. 2012. Agama Punya Seribu Nyawa. Jakarta: Noura Books. Karta

Mihardja, Achdiat. 2009. Atheis. Jakarta: Pustaka Balai.

Nurgiantoro, Burhan. 1995. Teori Pengkajian Fiksi. Yogyakarta: Gajah Mada University Press.

. 2002. Teori Pengkaji Fiksi. Yogyakarta: Gajah Mada University Press.

Piliang, Yasraf Amir. 2006. Dunia yang Dilipat. Yogyakarta: Jalasutra.

Ratna, Kutha. 2004. Teori, Metode, dan Teknik Penelitian Sastra Dari Strukturalisme Hingga Postrukturalisme Perspektif Wacana Naratif. Yogyakarta: Pustaka Pelajar.

. 2005. Sastra dan Cultural Studies Representasi Fiksi dan Fakta. Yogyakarta: Pustaka Pelajar.

$\begin{array}{lr}\text { Teknik Penelitian } & \begin{array}{r}\text { Metode, dan } \\ \text { Sastra dari }\end{array} \\ \text { Strukturalisme } & \text { hingga } \\ \text { Postrukturalisme: } & \text { Perspektif } \\ \text { Wacana Naratif. } & \text { Yogyakarta: } \\ \text { Pustaka Pelajar. } & \end{array}$ 2008. Postkolonialisme Indonesia: Relevansi Sastra. Yogyakarta: Pustaka Pelajar.

Santoso, Listiono, dkk. 2007. Epistemologi Kiri. Jogjakarta: Ar-Ruzz Media.

Sarup, Madan. 2011. Postrukturalisme dan Postmodernisme. Yogyakarta: Jalasutra.

Sarwono, Sarlito Wirawan. 2003. Teori-teori Psikologi Sosial. Jakarta: Raja Grafindo Persada.

Sudiarja, A. Agama di Zaman yang Berubah. 2006. Yogyakarta: Kanisus.
Suprayogo, Imam dan Tabroni. 2001. Dasar-Dasar Penelitian Kualitatif. (penerjemah Muhammad Shodiq dan Imam Muttaqien). Yogyakarta: Pustaka Pelajar.

2001. Metode Penelitian Sosial Agama. Bandung: Rosda Karya.

Dokumen:

Departemen Agama Republik Indonesia. 2000. Alquran dan Terjemahnya. Bandung: Diponegoro.

Departemen Pendidikan Nasional. 2008. Kamus Besar Bahasa Indonesia Pusat Bahasa. Jakarta: Gramedia.

Radar Bali. 2013. Selasa, 7 Mei 2013. "Tumpah Ruah Beragam Ekspresi", hIm 30.

Internet:

Abied.2010. Psikologi Persepsi. (dalamhttp://www.masbied.com/201 0/03/20/ psikologi-persepsi/.,dikses Juni 2013)

Andrhy. 2012. Ideologi Agama. (dalam http://andrhyblog.wordpress.com/20 12/06/23/makalah-ideologi-agama/., diakses Mei 2013)

Hafi Zha. 2010. Aspek Sosiologi dan Psikologi dalam Roman Atheis. (dalam http://rumahkata hafizha.blogspot.com/2010/07/aspe $k$ sosiologi dan psikologidalam.html., diakses November 2012).

Ihsani. 2011. Gambaran Pendirian Hidup dalam Novel Atheis Karya Achdiat Karta Mihardja. (dalam http://seketsaburam.wordpress.com/ 2011/07/11/gambaran pendirian hidup dalam novel atheis karya achdiat karta mihardja/.,diakes November 2012).

Meyqasari. 20012. Agama Menurut Karl Marx "Religion is the opium of the people". (dalam http://dwieayi90.blogspot.com/2012/ 
12/agama menurut karl-marxreligion-is_28.html., diakses April 2013)

Psychologymania. 2012. Agama dalam Pandangan Teori. (dalam <http://www.psychologymania .com/ 2012/02/agama-dalam-

pandanganteori.html., diakses $>$ Mei 2013).

Sastradyan. 2012. Resensi Novel Atheis. (dalam

http://sastradyan.blogspot.com/2009 110/resen si-novel-atheis.html., diakses Desember 2012).

Tuasikal, Muhammad Abduh (dalam http://remajaislam.com/islam dasar/akhlaq mulia/210 faktor penyebab tawuran kurangnya didikan agama dan perhatian-orangtua.html., diakses Mei 2013)

Yunita. 2012. Unsur Postkolonial dalam Novel Atheis Karya Achdiat K. Mihardja (dalam http://ejournal.unp.ac.id/index.php/p bs/article/view/201., diakses Desember 2012).

Wikipedia. $2012 . \quad$ (dalam http://id.wikipedia.org/wiki/Resistensi ., diakses Oktober 2012) (dalam . 2012. Atheis (novel). http://id.wikipedia.org/wiki/Atheis_(n ovel)., diakses Desember 2012).

2013 (dalam http://id.wikipedia.org/wiki/Kota_Den pasar., diakses Februari 2013)

$$
2013 \text { (dalam }
$$

http://www.duniapsikologi.com/pese psi-pengertian-definisi-dan-faktoryang-memengaruhi/., diakses Juni 2013) 